\title{
Hedge Accounting and Market Value of Quoted Manufacturing Firms in Nigeria: Panel Data Evidence
}

\author{
Alasin $^{1} \&$ Captain-Briggs ${ }^{1}$ \\ ${ }^{1}$ DBA, University of Port Harcourt, Rivers State, Nigeria \\ Correspondence:Alasin,DBA, University Of Port Harcourt, Rivers State, Nigeria
}

Received: November 26, $2017 \quad$ Accepted: November 30, $2017 \quad$ Online Published: December 16, 2017

\begin{abstract}
In a developing economy such as Nigeria, the business environment is characterized with risk that affects the operational efficiency and the performance of quoted firms. There is needed to make policies that will hedge against risk in the operating environment. This study examined the effect of hedge accounting on the market value of quoted oil and gas firms. A sample of 10 oil and gas firms was selected based on data quality and availability to address the requirements of the variables in the regression model. The study modeled market value as linear function of cash flow hedging, investment hedging and fair value hedging. Cross sectional data was sources from financial statement of the selected firms from 2011 to 2016. From the panel data result, (Fixed Effect Model) the study found that cash flow hedging have positive and significant relationship with market value while fair value hedging and investment hedging have positive but not significant relationship with market value of the quoted oil and gas firms. We therefore recommend that hedge accounting policies should be properly integrated to the operational objectives of the firms.
\end{abstract}

Keywords: Hedge Accounting, Market Value, Fair Value Hedging, Cash Flow Hedging, Investment Hedging.

\section{SECTION I: INTRODUCTION}

The business environment is very risky; this is because of the uncertainties that characterized the operating environment. Some of the risks emanate from the business known as systemic risk while others emanate from the external environment known as unsystematic risk. The cost of bearing risk is a crucial concept for any corporation. Most financial policy decision whether capital structure, dividend policy, investment or capital budgeting and hedging policies revolves around the benefits and cost of corporation holding risks (Daunfeldt, and Hartwig, 2012). The investment functions of the finance managers such as the capital budgeting requires an analysis of the future cash flows, uncertainties of future cash flows and values of these future cash flow (Adler,2000). The accounting information regarding hedging starts being more formally disclosed in annual reports in 2005 as a result of the new rules set by the Financial Accounting Standards Board (FASB). Also, since the mid of 2004, according to the FASB IAS 39 rules, firms were required to distinguish accounting information regarding hedging related transactions from the irunderlying exposures. The new information disclosure rules (IAS 39), introduced more transparency, particularly in the reporting of derivatives usage and related risk management policies 
A firm's value is equal to the net present value of all expected future cash flows. The fact that these future cash flows are expected emphasizes that they are uncertain (Eiteman et Al., 2004).Hedging means the process of offsetting exposure to business risks (Glaum and Klocker, 2011). In accounting point of view, financial hedging refers to designating financial instruments as an offset against the change in fair value or cash flows of hedged items with similar characteristics (Alfredson et.al, 2009). Transaction related to financial hedging is accounted under IAS 39: Financial Instrument, Recognition and Measurement. The scope of hedging comprises fair value hedging, cash flow hedging, investment hedging, foreign currency hedging, interest rate hedging, and debt hedging and operational hedging. Froot, Scharfstein and Stein (1993) and Leland (1998) opined that hedging is valuable when external financing is costly because it allows the firm to maintain its investment in states with low cash flow Leland (1998) shows that hedging increases the debt capacity of a firm.

The rules on hedge accounting in IAS 39 have frustrated many preparers, as the requirements have often not been linked to common risk management practices. The detailed rules have, at times, made achieving hedge accounting impossible or very costly, even where the hedge has reflected an economically rational risk management strategy. Similarly, users have found the effect of the current rules for hedge accounting less than perfect, and they have sometimes struggled to fully understand an entity's risk management activities based on its application of the hedge accounting rules. So, users and preparers alike supported a fundamental reconsideration of the current hedge accounting requirements in IAS 39. The new standard, IFRS 9, improves the decision-usefulness of the financial statements by better aligning hedge accounting with the risk management activities of an entity. IFRS 9 addresses many of the issues in IAS 39 that have frustrated corporate treasurers. In doing so, it makes some fundamental changes to the current requirements, by removing or amending some of the key prohibitions and rules within IAS 39. Theoretically, in the perfect capital market, firm's financial hedge is unnecessary as investors would be able to construct such hedges to financial risks on their own without any cost. But in the presence of market imperfection where asymmetric information, cost of financial distress, taxes, and other forms of imperfections exist, financial hedging is argued to be value creating. This is due to the fact that firm value will only be created when the firm makes a good investment which in turn increases their cash flows. The assumption of the perfect market has long been criticized as it does not exist in the real word. Therefore, this study intends to examine hedge accounting the the market value of quoted oil and gas firms.

\section{SECTION II: LITERATURE REVIEW}

\section{Concept of Hedge Accounting}

The accounting for derivative instruments at fair value creates a common issue for organizations that hedge risks using such instruments. Specifically, such organizations may face an accounting mismatch between the derivative instrument which is measured at fair value, and the underlying exposure being hedged, as typically underlying exposures are recognized assets or liabilities that are accounted for on a cost or an amortized cost basis, or future transaction that have yet to be recognized. This accounting mismatch results in volatility in the financial statements as there is no offset to the change in the fait value of the derivative instrument.

Hedge accounting provides this offset by effectively elimination/reducing the accounting mismatch through one of three ways

1. Through a Fair Value Hedge, which is achieved by accounting for the underlying exposure assets or liability (typically referred to as the hedged item) by adjusting the carrying value for changes in the hedged risk, which would then offset, to the extent effective, the change in the fair value of the derivative instrument, or

2. Through a Cash Flow Hedge where changes in the fair value of the derivative instrument are deferred in shareholders equity, to the extent effective, until the underlying exposure impacts the income statement 
in the future, or

3. Through a Net Investment Hedge which is a variation on a cash flow hedge, used to hedge foreign exchange risk associated with net investments in foreign currency denominated operations.

\section{FAIR VALUE HEDGE}

A Fair Value Hedge is used when an entity is looking to eliminate or reduce the exposure that arises from changes in the fair value of a financial asset or liability (or other eligible exposure) due to changes in a particular risk, such as interest rate risk on a fixed rate debt instrument. The hedged item is permitted to be measured at fair value each period in respect of the hedged risk (not for all risks) even if the hedged item is normally measured at amortized cost. Any resulting adjustment to the carrying amount of the hedged item related to the hedged risk is recognized in profit or loss even if such a change normally would be recognized in Other Comprehensive Income (OCI) - for example in the case of an instrument classified as available for sale.

\section{The Fair Value Hedge}

Measurement of Derivative Instrument

$\begin{aligned} & \text { Change in Fair Value } \\ & \text { Measurement of Hedged Item }\end{aligned}$
$\begin{array}{ll}\text { Change in Fair Value attribute to risk } \\ \text { hedged }\end{array}$

\section{CASH FLOW HEDGE}

A Cash Flow Hedge is used when an entity is looking to eliminate or reduce the exposure that arises from changes in the cash flow of a financial asset or liability (or other eligible exposure) due to changes in a particular risk, such as interest rate risk on a floating rate debt instrument. The hedged item is accounted for under normal principles. The hedging derivative instrument is measured at fair value each period however the effective portion of the change in fair value is deferred in OCI and presented within equity (normally in a hedging reserve). The difference between the effective portion of the change in the fair value of the derivative hedging instrument and full charge in the fair value (the ineffective portion) is recognized immediately in profit or loss. A Cash Flow Hedge only has measured ineffectiveness where the change in the fair value of the derivative instrument exceeds the change in the present value of the future cash flows of the hedged item/exposure (referred to as an "over hedge"). The change in fair value of the hedging instrument that is deferred in OCI is reclassified to profit or loss at a future date when the hedged item affects profit or loss (for example, when the interest payment on a floating rate debt instruments is made or when the payment associated with an anticipated transaction occurs).

\section{The Cash Flow Hedge}

Measurement of Derivative

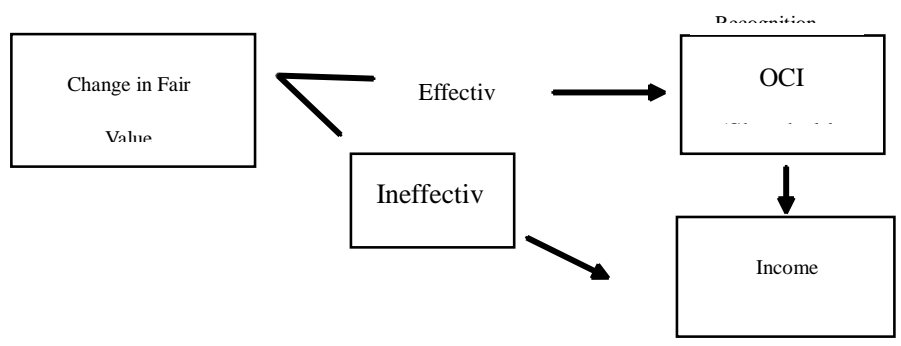




\section{NET INVESTMENT HEDGE}

\section{NET INVESTMENT HEDGE}

A Net Investment Hedge is a specific type of foreign currency cash flow hedge that is used to eliminate or reduce the foreign currency exposure that arises from an entity's Net Investment in a Foreign Operator (NIFO). Upon consolidation each period of the NIFO into the parent financial statements, a foreign currency gain or loss is recognized in shareholders' equity (part of the cumulative translation account). A Net Investment Hedge can be used to eliminate or reduce this volatility in shareholders' equity. The hedging instrument in a Net Investment Hedge can either be a derivative instrument (such as a foreign exchange forward contract) or a non-derivative instrument (such as a foreign currency denominated debt instrument), or a combination of a derivative and non-derivative under international accounting principles. When a derivative hedging instruments is used, the effective portion of the change in the fair value of the instrument is recognized in equity. The ineffective portion is recognized immediately I profit or loss. Similarly, when a non-derivative instrument is used, the foreign currency translation gain or loss is recognized in equity (as opposed to profit or loss).

Hedging means the process of offsetting exposure to business risks (Glaum and Klocker, 2011). In accounting point of view, financial hedging refers to designating financial instruments as an offset against the change in fair value or cash flows of hedged items with similar characteristics (Alfredson et.al, 2009). Theoretically, in the perfect capital market, firm's financial hedge is unnecessary as investors would be able to construct such hedges to financial risks on their own without any cost. But in the presence of market imperfection where asymmetric information, cost of financial distress, taxes, and other forms of imperfections exist, financial hedging is argued 
to be value creating. This is due to the fact that firm value will only be created when the firm makes a good investment which in turn increases their cash flows. However the ability to finance the investment opportunity is faced by financial risks exposure that can limit its financial flexibility. Hedging then will play a role to ensure that firm has sufficient cash when it needs it for investment without necessarily insulate them completely from all risks. Empirically, previous studies addressing these issues give a mixed result, nevertheless, some studies do indeed show the evidence that financial hedges create value (Allayanis and Weston 2001, Graham and Rogers 2002, Jin and Jorion 2006, Mackay and Moeller 2007). Aretz and Bartram (2010) extensively overviewed previous studies in corporate hedging and firm value. They summarized that hedging is value creating by exploiting the capital market imperfection that results in under-investment and assets substitution problem, costly divergent interest between manager and shareholders, costly external financing, cost of financial distress, and taxes.

Financial hedging is a common practice in many non-financial firms (Marshal 2000; Glaum 2002; Nguyen and Faff 2002; Glaum and Klocker 2011). The changing business environment has led firms to face financial risk on daily basis. With hedging, those firms strive to reduce the variability of their cash flows and as consequences reducing various cost associated with financial distress (Stultz, 1996). The most important financial risks faced by these firms are foreign exchange, interest rate, and commodity price risks (Servaes et.al 2009 in Glaum and Klocker 2011). In order to offset the exposure of these risks, a firm may use financial and also operational hedging. However, Allayannis et.al (2001) show that operational hedges, risk exposure hedging by means of real option 2 and put focus on providing operational flexibility, are not a perfect substitute of financial hedges. Moreover, Kim et.al (2006) found evidence that financial hedging is more effective than operational hedging due to the greater flexibility and lower capital investment requirements.

Most of the firms use derivatives as hedging instruments, moreover, current standards only allow derivatives as a hedging instrument for almost all hedge accounting type, non-derivatives financial assets and liabilities can only be used to hedge foreign currency risks on a net investment. Derivatives are financial instruments or other contracts that derive their value from another underlying item such as share price or interest rate. Derivatives usually do not require initial net investment, or if it is required the amount of the initial investment would be smaller than other similar type of contracts, and to be settled in the future date. Although derivatives can be used for speculative purpose, previous studies found evidence that firms use derivatives mostly for hedging purpose (e.g Tufano 1996, Guay 1999, Allayanis and Ofek 2001, Gezcy et.al 2007). As for this thesis, the discussion would not be limited to the use of derivatives as the hedge instrument like several previous studies (Glaum and Klocker 2011). Instead, the scope limitation would mainly be based on the IASB's standard for hedge accounting or in other words also taking into consideration the use of other financial instrument as hedge instrument as long as it is permitted by the standard.

\section{Accounting for Financial Hedge}

Transaction related to financial hedging is accounted under IAS 39: Financial Instrument, Recognition and Measurement. Accounting for financial instrument has been the most controversial area in IFRS adoption especially those related to hedge accounting. One thing that should be put into consideration before discussing hedge accounting is that IAS 39 was originally developed based on US GAAP standard for similar transaction namely SFAS 133: Accounting for Derivatives Instrument and Hedging Activities. As US GAAP tends to be identified as a rule-based standard (for example Schipper, 20034; Nelson, 2003; Bartov et.al, 2003), one can expect that IAS 39 would be more rule-based compared to other IASB's standards even though it is already amended several times. As consequence, hedge accounting under IAS 39 is very prescriptive, the standard's implicit preference is fair value measurement so that in order to qualify hedge accounting, an entity should 
comply strict specific criteria.

The fundamental problem of hedge accounting is that the effects arose from the transaction of hedged item and hedge instrument are economically correlated. With hedging, changes in fair value or cash flows from hedged items would be compensated by reciprocal change from the hedging instrument. Thus logically these transactions should be accounted in such a way that the hedged risks should not affect the income statement. If general IFRS rules are applied, those transactions should be accounted in an item by item basis. In addition, the gains and losses from those transactions are usually recognized in the different periods, making it not possible to offset each other and reflect risk management strategy. Moreover, hedging instruments usually are derivatives which therefore mark to market through income statement. The hedged item, on the other hand, will be accounted for differently using mixed-measurement model. It may be measured at cost or at fair value through other comprehensive income or not be recognized at all if the firm's hedged risks associated with forecast transactions. These accounting treatments will lead to earnings volatility that is economically unjustifiable.

Regarding these facts, under such circumstances hedge accounting is permitted. Hedge accounting means that fair value changes from hedge instruments are not recognized in the income statement but instead "parked" in equity or adjusted to the fair value of the corresponding hedged assets or liabilities. To be precise, IAS 39 categorizes hedge transaction in three relationship namely (1) fair value hedge a hedge of the exposure to changes in fair value of an asset, liability, or commitment; (2) cash flow hedge a hedge of the exposure to the variability of cash flows of a recognized asset or liability or a highly probable forecasted transaction; and (3) hedge of net investment in a foreign corporation which is accounted for in a similar manner as the cash flow hedge.

Under fair value hedge accounting, the gain and loss from hedging instrument remeasurement is recognized immediately in the profit and loss and so does the gain and loss from the hedged item attributable to the hedged risk will adjust its carrying amount and also recognized immediately in the profit and loss even when the hedged item is measured at cost. Through this mechanism, there would be no net effect in profit and loss when the hedge instrument is perfectly hedge (no ineffectiveness). In the case where ineffectiveness exists, such amount will be recorded in the profit and loss automatically since both gains and losses from hedged item and hedge instrument are recognized in profit and loss (IAS 39 par 89). When cash flow hedge is ac-counted, the portion of the gain and loss on the hedging instrument that is determined to be effective is recognized in equity as a hedging reserve while the ineffective portion is immediately reported in the profit and loss. The effective amount then will be "recycled" to profit and loss when the actual hedge transaction affects income statement (IAS 39 par 95-99).

In order to qualify a transaction as a hedge accounting transaction, IAS 39 also requires that a number of conditions must be cumulatively fulfilled. First, the firm must formally designate and document the hedging relationship at the inception of the hedge. Second, the hedging relationship must be expected to be 'highly effective' (80\%-125\%) and the effectiveness must be reliably measured and be assessed in ongoing basis throughout the duration of the hedge. Third, for hedges of forecast transactions such as cash flow hedge, it must be 'highly probable' that the transactions will take place (IAS 39 par 88). These requirements had caused many financial report users and preparers describe hedge accounting as complex and excessively rule based. IAS 39 also prohibits designating a net position as a hedged item since for reliability there must be a clearly identifiable relationship between the hedged item and the hedging instrument (IAS 39 par 78 and IAS 39 par 83-84). Such a relationship usually exists when individual items are hedged by individual hedging instruments (a micro-hedge). The standard allows firms to combine several hedged items only when they share the same risk exposure and the value changes of individual items in response to the risk factor are more or less proportionate to the value change of the whole portfolio. This is of course not the case with a net position made up of long and 
short positions. Thus the micro-hedge approach of IAS 39 is not compatible with the well-10

\section{Disclosure for Hedge Accounting}

From 2007 onwards, the requirement for hedge accounting disclosure is accounted for under IFRS 7: Financial Instrument Disclosure which replaces the old standard IAS 30: Disclosures in Financial Statements of Banks and Similar Financial Institutions and IAS 32: Financial Instrument Presentation. The general outcome of the full adoption of IFRS 7 is to present information to the users about firm's financial risk exposure and how those risks are being managed by the firm. In other words, the standard is aiming to provide the investors information about the impact of financial instrument onto profit and loss and how the entity manage the risks involved in financial activities. In broad, there are two types of disclosures in IFRS 7 namely (1) disclosures about significance of financial instruments for financial position and performance and disclosures about the nature which includes the statement of financial position, the statement of comprehensive income, and other disclosures and (2) disclosures about the extent of risks arising from financial instrument. Both categories include quantitative and qualitative disclosures. Application guide states that the disclosures shall be given either in the financial statements or incorporated by cross reference from the financial statement to some other statement such as management commentary or risk report.

Hedge accounting disclosures is regulated under paragraph IFRS 7 par 22-24 under other disclosure. Each type of hedge has different requirements, for each of them, description and the hedging instrument measured in fair value should be disclosed. Furthermore, the standard required more extensive disclosure for cash flow hedge. The objective of hedge accounting disclosure is to clarify what kind of risk is being involved in firm's hedging activity and to describe the type of financial instruments has been used as hedging instruments and the fair value of them. This fact is being criticized as some are of the impression that the current disclosure requirements do not provide sufficient information in the financial statements about the firm's risk management activities and focuses too strongly on accounting, which limits their understandability and usefulness. In addition, some also argue that disclosure requirements provided about hedge accounting today gives more focus on the hedging instruments that an entity has rather than on the entities risk management activities. The inability of hedge accounting to capture macro-hedging also led to some critics from financial statement users. Since hedge accounting application itself is not mandated, which means that firms who enter hedge transaction doesn't necessarily need to account such transaction under a hedge accounting standard, and given the complexity of the current standard, some firms choose to forgo the application of hedge accounting despite the fact that they are actually conducting a hedge transaction (Glaum and Klocker 2011).

\section{Determinants of Hedge Accounting Disclosure Level}

Given the research's objectives, there are several theories developed in previous studies relevant to be ad-dressed in order to develop the research hypothesis for the determinants of hedge accounting disclosure level. Despite the controversy of hedge accounting, at least to my knowledge, there are still limited studies addressing this topic. Therefore, below will be discussed (i) studies that give focus in voluntary disclosure8 especially those related to financial instruments and (ii) studies that investigate the motivation for firm's risk management. Verechia (2001) extensively reviewed and categorized accounting literature on disclosure in order to develop a firms' disclosure theory. He concludes that information asymmetry between stake holders and management reduction is the starting point of a comprehensive theory of disclosure. Using information asymmetric reduction as starting point will enable researchers to integrate the efficiency of disclosure choice, the incentive to disclose, and the endogenity of the capital market process. Moreover, Healy and Palepu (2001) also describe the demand of disclosure that arose from the fact that a market is imperfect which then lead to information asymmetry and agency conflict. Since management has an information advantage, voluntary disclosure can be used as a way to 
signal inside information which then result in a reduction of the information asymmetry and agency problems. Based on Healy and Palepu's review on empirical disclosure studies (2001), there are four categories in the disclosure literatures: (1) the role of disclosure regulation in reducing information and agency problems; (2) the effectiveness of auditor and financial intermediaries; (3) factor affecting decisions by managers on financial reporting and disclosures; and (4) the economic consequences of disclosures. The study about determinants of management's area would be the most relevant for the first research question. This literature has two main areas: (1) focusing on manager's accounting decisions based on positive accounting theory; and (2) focusing on management disclosure decision (voluntary disclosure literature) which is complementary for the first area. Positive accounting theory analyzing how managers choose their accounting policy and react to the new standard under the assumption that a firm is efficient and maximize their prospect to survive by minimizing their contract cost. In the other hand, voluntary disclosure studies give focus on stock market motives by assuming that managers have the information advantage. When the regulation and auditing are imperfect, manager trades-off between making accounting decisions and disclosures to communicate their superior knowledge of firm's performance to investors and managing reported performance for contracting, political or corporate governance reasons.

\section{Market value}

Value simply means the worth or importance of anything to a person. Value is seen in all spheres of life and is placed either individually or generally through an acceptable process. It follows therefore that there are various meanings of Value depending on the circumstance, the individual and the purpose. This is why such terms as intrinsic value, book value, market value, liquidation value and par value are found in business, management or financial parlances (Ngerebo-a, 2007).

Market value is based on supply and demand. It is used to refer to a company's market capitalization value. It is calculated by multiplying the number of shares issued by the price of the company's share. A company's share price is determined by daily trading between buyers and sellers on the relevant stock exchange. Market prices are easy to determine for assets as the constituent values, such as stock and futures prices, are readily available. The value of real estate assets are not as simple to determine, so real estate appraisers are required to provide a valuation. The same is true for businesses whose shares are not traded on a public exchange. A valuation would have to be prepared using a different method.

This is the value of an asset/security as determined by the forces of demand for and supply of the assets. It is the perceived or observed value of an asset on the market. It is also known as current value. It is in fact the mutually accepted worth (cost or price depending on the individual) of the asset after negotiation. Most assets that have market values have their values determined by specialized markets such as the stock exchange. The acceptance of any asset depends on the perception of the potential investor after comparing the market value to the intrinsic value. An asset is undervalued or under-price or favorably priced if the market value of the asset is less than the intrinsic value. If the intrinsic value of the asset is less the market value, then the asset is overvalued, over-priced or favorably priced. Where the latter occurs, the investor would ordinarily be acquiring an asset at more expensive value than he would ordinarily have paid. An investor would acquire an overpriced asset if he expects the asset to record a bullish price movement such that if the anticipated price movement crystallizes, the investor can make capital gain.

\section{REASONS FOR CORPORATE HEDGING}

\section{Investment Policy}

The neoclassical investment models (Hayashi, 1982) suggest that the firm faces frictionless capital markets and the Modigliani and Miller (1958) theorem holds. In reality, however, firms often face important external financing 
cost due to asymmetric information and managerial incentive problems (Gay \& Nam, 1998; Bolton, Chen \& Wang, 2011). This happens because the decline in a firm's stock price depends on the fact that the demand curve for shares is downward sloping, meaning that when the firm increases the amount of its shares will have to be sold at discount from existing market prices in order to attract new buyers.

The magnitude of the discount is an increasing function of the size of the issue (Scholes, 1972). There are a number of previous researches that try to measure these external financing costs. For instance, Asquith and Mullins (1986) find that the average stock price reaction to the announcement of a common stock issue is $-3 \%$ and the loss in equity value is $-31 \%$. One of the reasons why firms choose to hedge depends on the fact that they want to avoid underinvestment problem. That's to be said, firms might have some promising future's investments, but those investments require significant funding and firms need plenty of cash. Froot, Scharfstein and Stein (1993) argue that if external financing is more costly than internal financing, hedging can be a value increasing activity if it more costly matches fund inflows with outflows, thereby lowering the probability that a firm needs faces costs of external funds, it can reduce future financing costs by holding cash to finance its future investments such as lowering the probability that a firm needs to access to the capital market. In other word, hedging creates a positive association between potential underinvestment costs and the benefits of hedging.

\section{THE AGENCY PROBLEM}

In corporate finance theory, the principal- agency problem is explained by for example there are two individuals who operate in an uncertain environment and for whom risk sharing is desirable. Suppose that one of the individuals known as the agent is to take an action which the other individual known as the principal cannot observe. The problem arises when the principal cannot monitor the agent's behavior, leading to the agent acts in his self- interest at the expense of the principal (Grossman \& Hart, 1983). In general, the action, which is optimal for the agent will depend on the extent of risk sharing between the principal and the agent. Firm can reduce the risk imposed on other claim holders by hedging. To see this, let assume that shareholders hire managers for their specialized resources, but in the absence of monitoring shareholders will not know if the mangers really do their best in order to maximize the shareholders' value. One solution to the principal and agent problem is that the compensation contract must be designed so that when managers increase the value of the firm, they also increase their expected utility.

When the compensation ties to the manager's performance in term of the stock price movements, for the most part, stock price- related compensation schemes might consist of company stock or stock option programs. If the future's stock price can affect management's compensation, then the potential decline in stock price will intensify the risk aversion if undiversified managers. As a result, strong incentives are created for managers to reduce their risk aversion and to boost the stock price (Bartram, 2000). Nonetheless, the stock price movement does not depend only on the managers' performance but other determinants as well for example exchange rate or interest rate risks are clearly beyond the managers' control. As a result, due to the external influences unrelated to managers' performance on share price, management compensation plans are less effective (Aretz, Bartram \& Dufey, 2007). If managers and shareholders have different risk preferences, the firm may not be able to achieve its maximum value since the managers will be less like take risky investments. In order to solve this problem, the firm can employ a hedging program since it will reduce the impact of unrelated financial risks on firm value and help to secure the manager's compensation.

\section{Capital Structure Policy}

The transaction costs related to bankruptcy can be a deal breaker when it comes to hedging, recent empirical studies of hedging theories have paid significant attention to the impact of high leverage on firm' decision to hedge. Classic corporate finance theory tells us that while high leverage increase firm's value through the tax 
advantage of debt (Modigliani \& Miller, 1958) since it also puts pressure on the firm for a risk- averse investor will think twice before he puts money on a high leverage firm. Furthermore, in case firm doesn't meet its obligations to debt holders promptly, the firm may encounter financial distress and ultimately, bankruptcy (Aretz, Bartram \& Dufey, 2007). Financial distress costs consist of two forms: direct and indirect costs. Direct costs refer to a situation when in the case of bankruptcy; firms need to pay fees for lawyers, expert witnesses and administrative and accounting fees, while indirect costs relate to the situation when firms lose valuable contact with customers, suppliers or skillful employees. To demonstrate how hedging can minimize the risk of bankruptcy.

\section{THEORETICAL FRAMEWORK}

\section{Modigliani and Miller Hypothesis}

The basic idea of the Modigliani and Miller (M\&M) theorem is that under certain assumptions such as if the CAPM holds, then it does not matter how the firm chooses to finance its investment: either by issuing shares, borrowing debts or spending its cash. The financing method will not affect the value of a firm since firm value is determined by its earning power and by the risk of its underlying assets. For the theorem to hold, there are some criteria must be satisfied such as there are no taxes, no transaction costs and no bankruptcy cost (Ogden, Jen $\&$ O’Connor, 2003).

Conclusion, drawn from the MM proposition I \& II, is that in an efficient market when a firm value is not affected by the taxes, bankruptcy costs, agency costs and information asymmetry. It will not matter how a firm choose to invest in some projects, the value will be completely unaffected by the type of security firm used to finance the investment. In other word, regardless of the financing used, the marginal cost of capital to a firm equal to the average cost of capital, which is in turn equal to the capitalization rate for an unlevered stream in the class to which the firm belongs (M\&M, 1958).

\section{The Capital Asset Pricing Model (CAPM)}

The CAPM is a model for pricing an individual security or a portfolio. The CAPM model was developed independently by William Sharpe (1964), and Parallel work was performed by Lintner (1965) and Mossin (1966) these model marks the birth of asset pricing theory. The CAPM suggests that the only variables that we need in calculating the expected return on security are: the risk-free rate (a constant), the expected excess return on the market, and the security's beta (a constant). The CAPM model is attractive because of its effectively simple logic and intuitively pleasing predictions relating to how it measures risk and the relation between expected return and risk. Unfortunately, the CAPM simplicity causes the empirical record of model to be poor, poor enough to invalidate the method used in the application of the model. The models empirical problems may reflect true failings or they may also be due to the shortcomings of the empirical tests, most notably, poor proxies for the market portfolio of invested wealth, which plays a crucial role in the models predictions.

The CAPM is built on the model of portfolio choice developed by Harry Markowitz (1959). The Markowitz model is often known as a "mean-variance model" it describes the relationship between risk and the expected return of an asset under the conditions of market equilibrium in a capital market where all investors undertake optimal portfolio selection. The model assumes investors are not risk takers and that they care only about the mean and variance of their one-period investment return when choosing among portfolios.

\section{The Arbitrage Pricing Theory (APT)}

The Arbitrage Pricing Theory (APT) is another model of asset pricing based on the idea that equilibrium market prices should be perfect, in such a way that prices will move to eliminate buying and selling without risks (arbitrage opportunities). The basis of this theory is the analysis of how investors construct efficient portfolios and offers a new approach to explaining the asset prices and also states that the return on any risky asset is a linear combination of various macroeconomic factors that are not explained by this theory. Therefore unlike CAPM 
model this theory specifies a simple linear relationship between assets, returns and the associated $\mathrm{k}$ factors. There are two empirical testable versions of the APT, the statistical APT and the macro variable APT. However, the macro variable model differs from the statistical factor model mainly because the factors are specified in advance and they are interpretable.

The APT equilibrium rests on investors, ability to construct an arbitrage portfolio by simultaneously holding a short and a long position in two different portfolios which offers positive expected return with zero risk and zero net investment. Asserted risk-expected return relation is known as the Arbitrage Pricing Theory, Which is formulated by Ross (1976). It is probably safe to assume that both the CAPM and APT will continue to exist and will be used to price capital assets.

\section{Empirical review}

Pagah (2016) studied the relationship between hedging of just fuel price and the value of airlines operating in the European industry. The conclusion made from empirical overview on the topic, also presenting conflicting results, why further researches appear to be sought. Both the theoretical and empirical overview on the topic makes it fairly easy to imitate or extend this stud, in order to further investigations.

Sallyanne and Weston (2001) explained link between firm value and hedging. They find a statistically significant hedging premium of $48.7 \%$ for firms that do not have sales from foreign operations, resulting in a foreign currency exposure. They do also test the effects of reversal by setting up 3 hypotheses, testing whether the decision to begin or quit hedging is affected by the value of Tobin's Q. They found that both the decision to begin or quit hedging are not affected by Tobin's Q. by performing these tests, they conclude that the correlation between Tobin's $Q$ and firm value does not stem from reversal causality.

Carter, Rogers and Simkins (2006) investigate the fuel hedging behavious of American airlines. Like Allayannis and Weston they find evidence, that firm value is positively related to hedging. Additionally, they find that changes in firms hedging polices, are positively related to changes in firms' value. Jin and jorion (2006) conducts an investigation of firm value and hedging is the U.S. oil and gas industry. Contrary to carter et al. and Allayannis and Weston, they find no evidence that hedging increases firm value, they do however find, that hedging leads to a reduction in the firm's stock price sensitivity to oil and gas prices.

Perez-Gonzalez and Yun (2013) studied the relationship between firm value and hedging policy. Unlike prior studies, that primary focuses on endogen variables, perez-Gonzalez and Yun use the introduction of weather derivatives as an exogenous shock to firm's ability to hedge, and conduct a natural experiment. They found that firms with a high exposure to weather changes in less valuable and have more conservative financing polices, including less debt when introducing the weather derivative, the author discovers that firm with high exposure to weather volatility, are two to three times more likely to engage in weather hedges, than other utilities. They concluded that risk management has real consequences for the outcomes of the firms.

Chen, Han Zeng, (2015) investigated the real consequences hedging has no firm value. Findings reveal evidence that derivative users have higher CAR's around deal announcement than non-users, they find a "hedging premium" of approximately $0.9 \%$ compared to non- derivative users. Gilje and Taillard (2015) examined if hedging has causal effect on firm value. The decrease in shareholder value primarily origins from a decrease in shareholder value of firms with high ex ante leverage compared to firms with low ex ante probability of distress. These results can be linked to the theory.

Lailly (2011) studies hedge accounting disclosure practice under IAS 39 and IFRS 7 in listed firms in the Nether-lands. The results conclude that industrial sectors, listing status, firm's corporate governance, and profitability are the determinants of firm's hedge accounting disclosure level. Kevin and Gunter (2007) examined capital market imperfections, risk management and increase firm's value. The findings proved that when there 
are imperfections in capital markets, corporate hedging can enhance shareholder value through its impact on agency costs, costly external financing, direct and indirect costs of bankruptcy, as well as taxes.

Jakob Persson (2006) found that the use of currency derivatives in order to minimize the risk involved with foreign trade can also increase a firm's value. This is in line with the findings of Allayannis and Weston (2001) "Use of Foreign Derivatives and Firm Market Value which showed that companies in the U.S. that uses these currency derivatives has a higher firm value than companies that do not use them. Rossi and Laham (2005) examined the impact of company's hedging activities on firm value for a sample of non-financial Brazilian companies from 1996 to 2005 . The results show that hedging activities do increase the firm value.

Jin and Jorion (2004) showed a negative and statistically non-significant relation between the use of commodity derivatives and firm value. Clark et. al. (2006) using a sample of French companies, showed evidence that the use of currency derivatives does not affect firm value. Hagelin et. al. (2004) found evidence that the use of derivatives has a significant and positive impact on firm value. Judge (2003) found low support for the importance of taxes, or the managers' risk-aversion, or the presence of bankruptcy costs to determine the use of derivatives. Allayannis and Weston (2001) confirmed the existence of a positive and significant relation between the use of currency derivatives and firm value for a sample of American firms. Lookman (2004) in his analysis of the sample of oil and gas producers observed that hedging would aggregate value only to companies where the commodity risk is secondary and hedging would have a negative impact on the firms where the commodity price is a primary risk. Hagelin et. al. (2004) found evidence that hedging activities increase firm value. The authors found that companies that use currency derivative are negotiated with premium when compared to those that do not use them. Pramborg (2004) found a positive impact of hedging on firm value in case the firms use it to hedge its transaction exposure and an insignificant impact in case they use it to hedge its translation exposure.

Dan et. al. (2005) found no evidence on the direct impact of the use of currency derivatives on firm value for emerging markets. Rossi (2002) observed a reduction in the Brazilian firm's foreign exchange exposure in the shift from the fixed exchange regime to the flexible exchange regime. Hany, Alcino and Yilmaz (2014) examined the effect of hedging with financial derivatives on firm value and financial performance, relying on a new dataset which comprises information on 288 nonfinancial firms. Findings show that the effectiveness of the risk management practices varies significantly across the financial risks and the derivative used for hedging. The study specifically found relationship between interest rate risk hedging and firm financial performance is negative for the overall hedging but positive for the hedging with forward contracts.

Dhanani et al. (2007) relying on a questionnaire sent to 564 nonfinancial UK listed firms, investigate whether tax and regulatory arbitrage, managing the variability of reported earnings, managerial incentives, economies of scale and lowering the likelihood of financial distress are amongst the relevant reasons justifying managers' choices regarding interest rate risk hedging.

Bartram et al. (2011) based on a sample which includes 6,888 nonfinancial firms from 47 countries, show that the use of derivatives reduces firm's total risk, is positively associated with firm value and is more prevalent in firms with higher exposures to interest rate, exchange rate and commodity prices risks. Allayannis et al. (2012) show that the use of derivatives for exchange rate risk hedging is associated with a significant value premium for firms where there is a strong internal (firm-level) or external (country-level) governance.

Fauver and Naranjo (2010) found that relationship between hedging and firm value is negative when firms have weak corporate governance. Marami and Dubois (2012) show that "affirmative" covenants, such as those which require firms to comply with accounting rules, pay taxes and buy insurance, favours value creation and "voluntary" interest rate hedging do not have any effect on firm value. Aabo and Ploeen (2013) examined the effect of business internationalization on foreign exchange hedging and concluded that higher levels of 
internationalization can reduce the need for foreign exchange hedging and show that there is an inverse $\mathrm{U}$-shape relationship between internationalization and foreign exchange hedging for large listed nonfinancial German firms.

Shane (2009) reinvestigated the effect of foreign currency hedging with derivatives on firm value and found that foreign currency hedging is associated with an increase in firm value. Erik and Jérôme (2015) investigated hedging and its effects on firms value and found that firms affected by the basis risk shock reduce investment, have lower valuations, sell assets and reduce debt relative to control firms. Ngan (2015) intended to fill this gap and investigate the impact of hedging on firm value. Using Tobin's $Q$ as an approximation for firm market value and hedging as a control variable. The results of the regression analysis show insignificant indication that the usage of hedging impacts firm value positively. The findings of this research imply that there is no evidence that support the hypothesis that hedging causes an increase in firm value. None of the studies examined above focused on Nigeria, therefore it is imperative to examine the relationship between hedge accounting and market value of quoted oil and gas firms in Nigeria.

\section{SECTION III: RESEARCH METHODOLOGY}

Descriptive and longitudinal design will be employed with a view to making statistical inferences on the effect of hedging on market value of quoted oil firms. A Sampling frame of 10 quoted oil firms were selected using random sampling techniques. The required cross-sectional data were sourced from annual reports of the firms and stock exchange factbook from 2011-2016.

\section{Analytical Framework and Empirical Model Specification}

This analysis is carried out within a panel data estimation framework. The preference of this estimation method is not only because it enables a cross-sectional time series analysis which usually makes provision for broader set of data points, but also because of its ability to control for heterogeneity and endogencity issues. Hence panel data estimation allows for the control of individual-specific effects usually unobservable which may be correlated with other explanatory variables included in the specification of the relationship between dependent and explanatory variables (Hausman and Taylor, 1981). The basic framework for panel data regression takes the form:

In the equation above, the heterogeneity or individual effect is $Z^{i}$ which may represent a constant term and a set of observable and unobservable variables. When the individual effect $Z_{i}{ }_{i}$ contains only a constant term, OLS estimation provides a consistent and efficient estimates of the underlying parameters (Kyereboah-Coleman, 2007); hut if $Z^{\prime}{ }_{i}$ is un-observable and correlatedwith $X_{i t}$, then emerges the need to use other estimation method because OLS will give rise to biased and inconsistent estimates.

$Y_{i t}=\beta X^{\prime}{ }_{i t}+\alpha Z^{\prime}{ }_{i}+\varepsilon_{i t}$

Similarly for endogeneity issues, it is generally assumed that the explanatory variables located on the right hand side of the regression equation are statistically independent of the disturbance $\varepsilon_{i t}$ such that the disturbance term $\varepsilon_{i t}$ is assumed to be uncorrelated with columns of' the parameters $X_{i t}$ and $Z_{i t}$ as stated in equation (1), and has zero mean and constant variance $\sigma^{2} \eta$ (Hausman and Taylor, 198). If this assumption is violated, 
then OLS estimation will yield biased estimates of the underlying parameters of $\beta$ (Mayston, 2002).Hence, endogeneitv problems arise when the explanatory variables are correlated with the disturbance term $\varepsilon_{i t}$ (Mayston, 2002; Hausman and Taylor, 1981). In order to circumvent these problems, panel estimation techniques of fixed and random effects will be adopted in this study, in addition to the traditional pooled regression estimation. Decisions will be made between the fixed and random effect models using the Hausman specification test. The panel model for the study is specified base on the modified model of Akeem, Edwin, Kiyanjui and Kayode (2014).

$Y_{i t}=\beta X^{\prime}{ }_{i t}+\alpha Z_{i}^{\prime}+\varepsilon_{i t}$

Where:

$\mathrm{Y}=$ dependent variable

$\mathrm{D}=$ independent variable

$\beta_{o}=$ intercept

$\beta_{i}=$ coefficient of the explanatory variable

$\mathrm{e} \quad=$ error term

I $=$ cross-sectional variable

$\mathrm{T}=$ time series variable

Model Specification

Pooled regression specification

$M V_{i}=\alpha o+\alpha_{1} F V H_{1_{i}}+\alpha_{2} C F H_{2 i}+I N H_{3 i t}+\varepsilon 1_{i t} \quad 3$

Fixed Effect Model Specification

$M V_{i t}=\alpha o+\alpha 1 F V H_{1 i t}+\alpha_{2} C_{F H_{2 i t}}+I N H_{3 i t}++\sum_{i}^{9}=1 \alpha_{i} i d u m+\varepsilon 1_{i t}$ 4

\section{Random effect model specification}

$M V_{i t}=\alpha o+\alpha_{1} F V H_{1 i t}+\alpha_{2} C F H_{2 i t}+a_{3} I N H_{3 i t}+\mu i+\varepsilon 1_{i t}$

Where

$\mathrm{MV}=$ Market Value of quoted oil and gas firms

$\mathrm{FVH}=\quad$ Fair Value Hedging measured as exposure to change in fair value of investment

$\mathrm{CFH}=$ Cash flow hedging measured as exposure to variability of fixed assets

$\mathrm{INH}=$ Investment hedging measured as variability of change of net investment

$\mathrm{t}=$ Stochastic or disturbance/error term.

$\mathrm{t}=$ Time dimension of the variables

$\alpha 0=$ Constant or intercept.

\section{SECTION IV: RESULTS AND DISCUSSION \\ SECTION IV: RESULTS AND DISCUSSION OF FINDINGS}

The following tables explain the dynamic relationship between hedging and the value of Nigeria quoted oil and gas firms.

Table 1: Testing the significant of pooled effect model: redundant test 


$\begin{array}{llll}\text { TEST } & \text { STATISTICS } & \text { DF } & \text { PROB }\end{array}$

\section{Hausman Test}

Test Summary

Cross-section random

Chi-Sq. Statistic

67.78491

Chi-Sq. d.f.

7

Chi-Sq. d.f.

Prob.

Chi-Sq. Statistic

Prob.

\section{Source: Extract from E-view (9.0)}

In testing the validity of the models, the fixed effects on the cross section Redundant Fixed Effect- Likelihood Ratio, the P-value is 0,000 indicating that the effects are significant. Select the random effect and perform the Correlated Random Effects- Hausman test, testing the random effects model against the fixed effects model. The null hypothesis in that case is that both tests are consistent estimators and the random effects model is efficient. Under the alternative hypothesis, only the fixed effect is consistent. Since the p- value is 0.000 , the null hypothesis is rejected and, therefore, the fixed effects model is to be preferred.

TABLE II: PRESENTATION OF LEVEL SERIES RESULT

\begin{tabular}{|c|c|c|c|c|c|c|c|c|c|}
\hline \multirow[t]{2}{*}{ Variable } & \multirow{2}{*}{$\begin{array}{l}\text { Pooled Effect } \\
\beta \text { coefficient }\end{array}$} & \multirow[b]{2}{*}{ T. stat } & \multirow[b]{2}{*}{ p. value } & \multicolumn{3}{|l|}{ Fixed effect } & \multicolumn{3}{|c|}{ Random effect } \\
\hline & & & & $\begin{array}{l}\beta \\
\text { coefficient }\end{array}$ & T. stat & p. value & $\begin{array}{l}\beta \\
\text { coefficient }\end{array}$ & T. stat & p. value \\
\hline FVH & 0.269504 & 0.251836 & 0.8034 & 0.642134 & 0.957887 & 0.3490 & 0.255108 & 0.260885 & 0.7966 \\
\hline $\mathrm{CFH}$ & 0.573730 & 1.904431 & 0.0694 & 8.090366 & 2.077387 & 0.0502 & -0.921031 & -1.425625 & 0.1680 \\
\hline NIH & 0.839990 & 0.610587 & 0.5475 & 0.278071 & 1.183498 & 0.2498 & 0.510182 & 0.511865 & 0.6138 \\
\hline$\beta$ & 0.846544 & 0.496401 & 0.6243 & 0.394870 & 0.380741 & 0.7072 & -1.196181 & -0.697472 & 0.4928 \\
\hline R-squared & 0.328834 & & & 0.664475 & & & 0.486773 & & \\
\hline $\operatorname{Adj}^{2}$ & 0.095386 & & & 0.504701 & & & 0.276817 & & \\
\hline F-statistic & 1.408593 & & & 4.158842 & & & 2.318449 & & \\
\hline F- Prob & 0.245320 & & & 0.002869 & & & 0.052007 & & \\
\hline D W & 3.332592 & & & 2.115321 & & & 3.192437 & & \\
\hline
\end{tabular}

Source: extract from E-view 9.0

\section{Discussion of Results}

\section{R-squared}

The co-efficient of multiple determinations which is the $\mathrm{R}^{2}$ is 0.66 . This means that the regression model captures as much as $66 \%$ of the total variation in market value of the quoted oil and gas firms.

\section{Adjusted R-squared}

The co-efficient of multiple determinations which is the R2adjusted is 0.50.4 This means that the regression model captures as much as $50.4 \%$ of the total variation in market value of the oil and gas firms after adjusting for errors.

\section{F-statistics}

The F-statistic which is the joint test of significance of all the parameter estimates shows that it is significant at both the five percent and one percent levels i.e calculated (4.158842) is greater than tabulated. This implication of this is that the R2 is statistically significant and the populations from which the samples are drawn do differ significantly.

\section{Durbin Watson test}

The Durbin Watson statistic also show that we are justified in carrying out a test of significance and our results are reliable since the result show that there is no autocorrelation (with a DW of 2.11521).

\section{Fair Value Hedging}

There is a positive and significant relationship between fair value hedging of the oil and gas firms in our 
analysis and the market values. The result shows that a one percentage point increase or appreciation in the fair value hedging of the firms improves market value by 6.4 percentage points in the current year. This implies that there is a strong positive relationship between the fair value hedging of the firms under study and the market value. The greater the greater hedging policies employ, the stronger will be its market value given that other things are held constant.

\section{Cash Flow Hedging}

Our result shows that there is a positive relationship between cash flow hedging and market value of the oil and gas firms and this relationship is statistically significant ( $t$ value of 2.077). From the above table, a one percentage point increase in cash flow hedging results in a 8.0 percentage increase of the market value of the firm. The results shows that cash flow hedging in the within period to the Gordon's theory of relevance of financial policies such as capital structure and dividend policy.

\section{Investment Hedging}

There exists a positive relationship between the rate of investment and financial market value and this relationship is statistically. The coefficient implies that a unit increase in investment hedging will lead to 0.2 percent increase in market value of the quoted oil and gas firms. Coefficient of the T-statistics and the probability value shows that the independent variable is statistically not significant.

\section{SECTION V: CONCLUSION AND RECOMMENDATIONS}

Hedge accounting is a useful financial reporting accommodation that is not as complex and mystifying as it may appear at first glance. It is particularly useful for organizations that experience financial statement volatility today as a result of using derivatives to hedge underlying financial and/or non-financial risks (or expect to do so in the future). It does nevertheless require a level of expertise to ensure it is being appropriately and an investment of time and resources both an inception of a hedge relationship and an on-going basis to maintain it. The consequences of not applying hedge accounting appropriately can be significant, resulting in financial restatements. However, when applied appropriately, hedge accounting can result in a better alignment of an organization's financial reporting and economic realities. From the above this study concludes that there is significant relationship between hedge accounting and market value of quoted oil and gas firms in Nigeria. We therefore recommend that hedge accounting should be integrated to the operational objectives of quoted firms and hedge accounting should be properly complied with as contained in international accounting standard.

\section{REFERENCES}

Alfredson, K et.al (2009). Applying International Financial Reporting Standard. Wiley, 2nd Edition

Aretz, B., \& Dufey. (2007).Why hedge? Rationales for corporate hedging and value implications. The Journal of Risk Finance, 8 (5), 434-449

Bartram, S. M. (2000).Corporate risk management as a lever for shareholder value creation. Financial Markets, Institutions and Instrument, 9 (5), 279- 324

Bolton, M., Chen, H. \& Wang, N. (2001) .A Unified Theory of Tobin's q, Corporate Investment, Financing, and Risk Management. The Journal of Finance 23( 5),156-179.

Bolton, M., Chen, H. \& Wang, N. (2001).A Unified Theory of Tobin's q, Corporate Investment, Financing, and Risk Management. The Journal of Finance 3(9),45-89.

Carter, D; Rogers, D., Simkins, B. (2006). Does hedging affect firm value? Evidence from the US airline industry. Financial Management, Spring 4(5), 53-86.

Carter, D.A., Daniel, A, R., \& Betty, J, S., (2016). Does Hedging affect firm value? Evidence from the US Airline holustry "financial management, 35(1), 1-38. 
Chen, Z., Bo, H., \& Yeguin, Z., (2015). Does Corporate Financial Risk Management Add Value? Evidence from Cross-Border Merger and Acquisitions. (Retired on $15^{\text {th }}$, August 2017).

Clark, E.; Judge, A.; Mefteh, S. (2006). Corporate Hedging with Foreign Currency Derivatives and Firm Value. Unpublished paper. 4(5), 45-79.

Dan, C.; Gu, H.; Xu, K. (2005). The impact of hedging on stock return and firm value: new evidence from Canadian oil and gas companies. Unpublished paper.

Eiteman D.K., Stonehill A. I., Moffet M. H., (2004). Multinational Business Finance, PearsonEducation, Pearson Addision Wesley

Froot, K., Schrfstein, D., Stein, J. (1993). Risk Management: Coordinating Corporate Investment and Financing Policies. The Journal of Finance,. 4(8),1629-1658.

Gay, D. G., \& Nam, J., (1998). The Underinvestment Problem and Corporate Derivatives Use. Financial Management, 4(5),3- 69

Gilje, E., \& Jerome, T., (2015). Does Hedging affect firm value? Evidence from a National Experiment (Retrieved on $16^{\text {th }}$ August, 2017).

Glaum, M., \& Klocker, A., (2011). When the tail wags the dog: Hedge Accounting and its influence on financial hedging. Accounting and Business Research (forthcoming). IAS 39: Financial Instrument, Recognition and Measurement. . London: International Accounting Standards Board

Grossman, S. \& Hart, O. (1983) “An Analysis of the Principal- Agent Problem”, Journal of The Econometric Society,(5)1, 17-45

Hagelin, N. (2004). Hedging foreign exchange exposure: risk reduction from transaction and translation hedging. Journal of international Financial Management and Accounting. 15(1) 1-20.

Hagelin, N., (2003).Why firms hedge with currency derivatives: An examination of transaction and translation exposure.Applied Financial Economics, 1(3), 55-69

Harry, A., Alano A., \& Yilmaz, G., (2012). The Effect of Hedging on firm Value and performance: Evidence from the non financial UK firms. 61(2), 62-89.

Hausman, J. A., \& Taylor, W. E., (1981). Panel Data and Unobservable Individual Effect, Econometrical, 49(6), 1377-1398.

Hayashi, F., (1982). Tobin's Marginal q and Average q: A Neoclassical Interpretation”, Econometrical, 50(1), 213-224

Jakob, P., (2012). Can Hedging Affect firm's market value. A study with help of Tobin's Bachelor thesis within finance economics. Jonbkoping International Business School. 61(2), 62-89.

Jin, Y., \& Philippe, J., (2016). Firm Value and Hedging: Evidence from the US Oil and Gas producers. The Journal of Finance, 61(2), 62-89.

Jose, M. B., Amiyatosh, P., ～\& Uday, R., (2011). Corporate Hedging, investment and value.4(6), 76-90.

Kelvin, A., Sohnke, M, B., \& Gunter, D., (2007). Why hedge? Rationalist for corporate hedging and value implications. The Journal of Risk Finance 8(5), 434-449.

Kyereboah-Coleman, A., (2007). The impact of capital structure on the performance of microfinance institutions. Journal of Risk Finance, 8 (7),56-71.

Lailly, P., (2011). Hedge Accounting Disclosure Under /AS 39 and IFR87: Analysis of hedge accounting disclosure policy in the Netherland's Department of Accountancy, University of Tilburg. 61(2), 62-89.

Lawal B, A., Edwin T, K., Monica W, K., \& Adisa M, K., (2014). Effects of Capital Structure on Firm's Performance: Empirical Study of Manufacturing Companies in Nigeria. Journal of Finance and Investment Analysis, 3(4), 39-57. 
Lookman, A., (2004). Does hedging increase firm value? Evidence from oil and gas producing firms. Unpublished paper.

Mayston, D. J., (2002). Tackling TheEndogeneity Problem When Estimating the Relationship between School Spending and Pupils' Outcome, DFEE Research Report 328, Department Of Education and Skills, London.

Modigliani, F. \& Miller, M. (1958). The cost of Capital, Corporation Finance and The Theory of Investment. The American Economic Review, Vol. XLVIII, No. 3

Ngan, N., (2015). Does Hedging Increase firm value? An Examination of Swedish companies. A master Thesis in Lund University.

Ngerebo-a, T. A (2002). Corporate Financial Management 1: The Blueprint Limited, Port Harcourt.

Ogden, J.P., Jen, F.C. \& O’Connor, P. F. (2003). Advanced Corporate Finance: Policies and Strategies. Prentice Hall

Pagh, A., (2016). Hedging and firm value in the European Airline industry. Master Thesis Submitted to the Department of Economics and Business Administration. Copenhangen Business School. 61(2), 62-89.

Pandey, I. M., (2015). Financial management (8th ed.). New Delhi: Vikas Publishing House PVT Ltd.

Perez-Gonalez, F., \& Hayong, I., (2013). Risk Management and Firm Value. Evidence from Weather Determinants. The Journal of finance, 67(5), 189-217.

Pramborg, B. (2004). Derivatives Hedging, Geographical Diversification, and Firm Market Value. Journal of Multinational Financial Management, 1(4),117-133.

Rossi, J., (2005). Foreign Exchange Exposure, Corporate Financial Policies and the Exchange Rate Regime: Evidence from Brazil. Unpublished paper.

Scholes, M., (1972).The marker for securities: Substitution versus price and the effects of information of share prices. Journal of Business, 4(5), 179-211

Stultz, R,M., (1996). Rethinking Risk Management. Journal of Applied Corporate Finance, 9(3), 258-289.

\section{Copyrights}

Copyright for this article is retained by the author(s), with first publication rights granted to the journal.

This is an open-access article distributed under the terms and conditions of the Creative Commons Attribution license (http://creativecommons.org/licenses/by/4.0/) 